\title{
ПСИХОЛОГІЧНІ ОСОБЛИВОСТІ ПРОЯВУ ГЕНДЕРНОЇ ТОЛЕРАНТНОСТІ В ЮНАЦЬКОМУ ВІЩІ
}

\author{
Олена Праченко \\ старший викладач кафедри психосоматики \\ та психологічної реабілітації \\ Національний педагогічний університет імені М. П. Драгоманова \\ 01601, Україна, м. Київ, вул. Пирогова, 9 \\ o.k.prachenko@npu.edu.ua, https://orcid.org/0000-0001-5174-2547
}

\begin{abstract}
Анотація
Статтю присвячено визначенню психологічних особливостей прояву гендерної толерантності та іiі структурних компонентів в юнацькому віці. Зазначений віковий період знаменується виникненням нової соціальної ситуації розвитку, центром якої є перехід до самостійного життя. Продовжується інтенсивний розвиток самосвідомості, молоді люди самовизначаються в системі моральних цінностей, принципів, норм і правил поведінки, усвідомлюють особисту соціальну відповідальність. Відповідно до такої ситуації розвитку молодого покоління в умовах трансформаційних процесів в економічній, політичній i соціальній сферах, важливим є питання гармонізації міжстатевих стосунків молоді завдяки вихованню толерантного ставлення до представників своєї та протилежної статі. Прояв гендерної толерантності в юнацькому віці сприяє: створенню психологічно комфортних умов для спільної діяльності представників обох статей; досягненню міжособистісного й міжгрупового взаємопорозуміння і поваги в різних сферах життєвої взаємодії; забезпеченню ефективних психолого-педагогічних умов для вироблення у юнаків і юнок необхідних індивідуально-особистісних якостей щодо успішного протистояння стереотипним уявленням і тиску соціуму. Мета статті полягала в дослідженні психологічних особливостей прояву гендерної толерантності та сформованості іï компонентів у юнаків та юнок. У процесі емпіричного дослідження була використана: методика «ВIКТІ: види та компоненти толерантності» (авт. Г.Л. Бардієр), кількісний та якісний аналіз отриманих результатів проводився за шкалами «гендерна толерантність», «когнітивний компонент», «афективний компонент», «діяльнісно-стильовий компонент» гендерної толерантності. Констатовано, що майже в половини представників юнацького віку рівень гендерної толерантності знаходиться на середньому (наближеному до низького) рівні; майже третина юнацтва має низький рівень гендерної толерантності; й лише п'ята частина має сформовану гендерну толерантність (високий рівень). При аналізі сформованості складових гендерної толерантності (когнітивної, емоційної, поведінкової) встановлено, що знижені показники більше властиві хлопцям, що виявляється в зниженій рефлексивності, обмеженій емоційній і поведінковій саморегуляції.
\end{abstract}

Ключові слова: толерантність, гендерна толерантність / інтолерантність, когнітивний компонент гендерної толерантності, емоційний компонент гендерної толерантності, поведінковий компонент гендерної толерантності. 


\section{Вступ}

Визначальними показниками останнього століття та початку нового тисячоліття виступають політична, економічна, соціальна нестабільність у суспільстві, зростання i суперечливість в потоці інформації інноваційних технологій, глобалізація і розширення міжкультурної сфери взаємодій між людьми, трансформації управлінського та освітянського просторів. Відповідно до таких перетворень, зростають вимоги до соціального, професійного та особистісного становлення молодої людини в сучасних умовах іiі життєдіяльності. Це сприяло зростанню активної уваги вчених до розробки наукових положень щодо розвитку гендерної толерантності у юнаків і юнок з метою підвищення їхнього особистісного i професійного розвитку, оптимізації гендерної культури і рівності, виробленню навичок протистояння стереотипним уявленням соціуму.

Аналіз зарубіжної й вітчизняної психологічної літератури з проблеми дослідження толерантності з позиції гендерних стосунків, засвідчив, що на сучасному етапі немає єдиного тлумачення поняття «гендерна толерантність». У соціальній психології гендерна толерантність вживається в різних сенсах. Для прикладу, деякі вчені використовують поняття «гендерна толерантність» в невизначено-негативному сенсі. Для них вона є, свого роду, неприродною стриманістю, існуванням особистісних переконань і цінностей, що можуть суперечити іншим. Вони розглядають гендерну толерантність у системі міжстатевих стосунків, як установку на ліберальне прийняття моделей поведінки, переконань і цінностей представників обох статей (Баева, 2009; Мацьковський, 1995; Оконешникова, 2004).

В межах інтегрального підходу гендерну толерантність визначають як складну, багатогранну, багатокомпонентну якість особистості. Вона містить, як терпимість, так і якості особистості, що виявляють позитивне ставлення до представників своєї й протилежної статі. Інтегральний підхід до суті гендерної толерантності дозволяє відзначити, що толерантність в системі гендерних стосунків $\epsilon$ складним, рівневим соціально-психологічним феноменом (Солдатова \& Филилеева, 2006).

Проаналізувавши наукові джерела, можемо зробити висновок про те, що гендерна толерантність - це цілісна індивідуально-групова та соціально-прийнятна характеристика особистості, яка дозволяє встановлювати і підтримувати якісні стосунки з представниками своєї й протилежної статі на рівні співробітництва, кооперації й компромісів.

Спираючись на зазначене вище, доцільно констатувати, що гендерна толерантність не може зводитися до однієї конкретної якості, а отже, має складну структуру. Як соціально-психологічне явище, вона є сукупністю психологічних сторін особистості, що компонують ii за допомогою виокремлення таких компонентів: когнітивного - знання i досвід толерантних міжстатевих стосунків, усвідомлення і прийняття відмінностей; емоційного - усвідомлення емоційних станів і процесів як власних, так і представників протилежної статі; поведінкового - саморегуляція поведінкових проявів, спрямованість на партнерські стосунки з представниками протилежної статі. Сформованість і комплексне поєднання цих компонентів сприятиме розвитку потенціалу гендерної толерантності.

Вивчаючи проблему гендерної толерантності, науковці відзначають доцільність іiі розвитку впродовж усього життя. Проте, на нашу думку, одним із сенситивних періодів $\epsilon$ саме юнацький вік. Як зарубіжні, так і вітчизняні дослідники цього вікового періоду зазначають, що саме в юності завершуються процеси біологічного дозрівання, а однією 3 найважливіших потреб особистості стає інтелектуальний розвиток, також посилюється 
емоційна стабільність, а в міжособистісних стосунках важливого значення набуває спілкування 3 ровесниками, особливо 3 представниками протилежної статі та одночасно тривають процеси саморозвитку і самовдосконалення (Кон, 1989; Ериксон, 2000).

Сучасні психологи відзначили, що прояв гендерної толерантності в юнацькому віці пов'язаний зі зростанням потенціалу емоційної зрілості, відкритості (Kuzmenko, 2019), збагаченням життєвого досвіду, актуалізацією власної життєвої позиції як результату підвищеного інтересу до себе, розвитком комунікативної й особистісної рефлексії (Малихін, 2017), дозріванням когнітивних та емоційно-вольових процесів (Рибалка, 2018), формуванням почуття культурної, соціальної та статевої ідентичності (Ставицька, 2014), розвитком етнічної самосвідомості (Stavytskyi, 2019), становленням соціальної, міжетнічної та особистісної толерантності (Павелків, 2011).

Реконструкція традиційних культурних обмежень розвитку потенціалу особистості залежно від статі, створення умов для максимальної самореалізації хлопців і дівчат $\epsilon$ найважливішою метою гендерного підходу в освіті (Grünberg, 2011). Розвиток гендерних підходів сприяє розвитку гармонійних партнерських міжстатевих стосунків, виховує їх у напрямку гендерної толерантності (Надолинська, 2008).

Отже, аналіз наукової літератури з обраної проблеми засвідчив їі недостатню розробленість, зокрема не вивченим залишилося питання прояву гендерної толерантності й сформованості її компонентів у юнацькому віці.

Мета дослідження: вивчити психологічні особливості прояву гендерної толерантності та сформованість іiі компонентів у юнаків та юнок. Завдання дослідження: 1) підбір і проведення методик для дослідження прояву гендерної толерантності в юнацькому віці; 2) вивчення iii структурності та рівнів сформованості когнітивного, емоційного й поведінкового компонентів.

\section{Методи дослідження}

В емпіричному дослідженні взяли участь 60 осіб юнацького віку (з них 30 хлопців і 30 дівчат), студентів II-III курсу факультету психології, спеціальності 053 - «психологія» денної форми навчання. Дослідницька робота проводилась у три етапи.

Для емпіричного дослідження особливостей прояву гендерної толерантності та сформованості їі компонентів у юнаків та юнок було обрано методику «ВІКТІ: види і компоненти гендерної толерантності» (авт. Г. Бардієр). До уваги взято результати за шкалами «гендерна толерантність», «когнітивний компонент», «афективний компонент» (емоційний) i «діяльнісно-стильовий» (поведінковий) компоненти гендерної толерантності.

\section{Результати та дискусії}

Аналіз особливостей прояву гендерної толерантності та сформованості їі компонентів, першочергово здійснювався 3 позиції виявлення показників та особливостей цього явища за статевими ознаками.

Дослідження гендерної толерантності особистості юнацького віку 3 позиції іï структурності реалізовувалося шляхом аналізу сформованості піi компонентів: когнітивного - містить такі складники, як досвід і навички міжстатевої взаємодії. Їх розвиток сприяє усвідомленню відмінностей між представниками різних статей, удосконаленню особистісних якостей, які необхідні для подальшої оптимізації міжстатевих стосунків; емоційного - характеризується емоційною стійкістю, ціннісним ставленням до 
емоційних станів, як власних, так і інших людей. Сформованість цих складників сприятиме усвідомленню власних емоційних виявів, розвитку емпатійності, емоційної чуттєвості, прийняттю емоційних станів інших, які є орієнтирами успішної, продуктивної міжстатевої взаємодії й, відповідно, гендерній толерантності; поведінковий - містить гнучкість поведінкових проявів, спрямованість на компромісне вирішення конфліктних ситуацій, що впливає на вміння свідомо керувати власними діями при міжстатевій взаємодії.

Отримані результати подано в табл. 1.

Таблиия 1

Кількісні показники сформованості компонентів гендерної толерантності в юнаків та юнок (y \%), $n=60$

\begin{tabular}{|c|c|c|c|c|c|c|}
\hline \multirow{2}{*}{ Компоненти } & \multicolumn{3}{|c|}{ Дівчата } & \multicolumn{3}{|c|}{ Хлопці } \\
\hline & 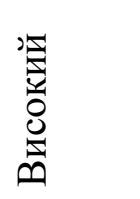 & 罸 & 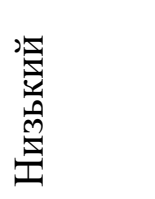 & 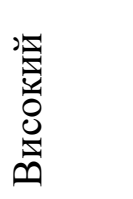 & 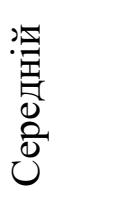 & 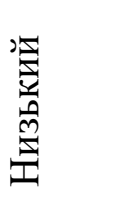 \\
\hline Гендерна толерантність & 12,00 & 67,30 & 20,70 & 1,40 & 18,00 & 80,60 \\
\hline Когнітивний & 20,70 & 66,70 & 17,30 & 2,00 & 43,00 & 54,20 \\
\hline Емоційний & 9,30 & 65,70 & 24,00 & 0,70 & 43,00 & 56,30 \\
\hline Поведінковий & 14,00 & 66,70 & $19,30 \%$ & 2,80 & 41,70 & 55,50 \\
\hline
\end{tabular}

Кількісний аналіз показників дозволив виявити високий рівень гендерної толерантності у $12,00 \%$ дівчат та 1,40\% хлопців. Досліджувані осмислюють, усвідомлюють і визнають різноманітність соціального устрою, не схильні до стереотипного ставлення до представників протилежної статі, їх соціальної та професійної діяльності. Володіють ціннісним ставлення до представників протилежної та власної статі, усвідомлюють як власні емоційні процеси, так і переживання інших людей, не дратуючись і не надаючи їм негативного сенсу. Також вони орієнтовані на конструктивну взаємодію з представниками протилежної статі в усіх сферах життєдіяльності; свідомо уникають конфліктів, вміють досягати домовленостей, не використовують агресивних поведінкових дій, доводячи свою точку зору; в процесі комунікації керуються логікою, аргументованістю та розкривають позитивні сторони необхідної інформації.

Середній рівень гендерної толерантності був визначений у 67,30\% дівчат і 18,00\% хлопців. Ці респонденти схильні до прояву толерантності / інтолерантності дозовано до відповідних, лише для них прийнятних ситуацій, людей, цінностей, думок і спрямувань, а також у ситуаціях особистої вигоди. Свої знання та моделі толерантної поведінки вони використовують з позиції егоїстичності, раціоналізму, спрямованості на власні переживання і потреби. Водночас, такі особистості визнають необхідність у пом'якшенні гендерних стереотипів, хоча і слідують деяким з них. При оцінці опонентів керуються принципом «норми», визнають права на відмінності лише вербалізовано. В певних ситуаціях виявляють байдужість або прискіпливість до представників протилежної статі, а у випадку відсутності бажання взаємодіяти, приховують свої негативні емоції, публічно демонструють неусвідомлену емпатійність через побоювання соціального невизнання чи осуду. Спрямовані на міжстатеву вазємодію, яка, переважно, має егоїстичну основу, проте, можуть бути нетерплячими до сильних емоційних провів опонента. 
Показники низького рівня гендерної толерантності діагностовано в 80,60\% юнаків та $20,70 \%$ юнок. Для них властиві прояви інтолерантності, обмеженість у поглядах, односторонність аналізу потреб, мотивів і бажань, впевненість в унікальності та переважанні характеристик власної статі. В процесі соціалізації вони чітко слідують нормам, правилам і стереотипам, які визначені у конкретному суспільстві та вимагають цього від оточуючих, не схильні до саморозвитку. Емоційні реакції таких юнаків і юнок, часто, непередбачувані, бурхливі і недиференційовані. У міжстатевій взаємодії вони демонструють незацікавленість через очевидну роздратованість й агресивність, рідко виявляють позитивне i доброзичливе ставлення до суб’єктів взаємодії, часто виступають провокаторами i приймають участь у конфліктах ситуаціях.

Отже, проведений аналіз результатів дослідження рівня гендерної толерантності за статевою належністю засвідчив, що більше, ніж половина дівчат і майже п'ята частина хлопців схильні до прояву толерантних якостей у міжстатевій взаємодії. На нашу думку, це свідчить про усвідомлення юнаками та юнками врахування доцільності статевих відмінностей, зорієнтованість на гендерну рівність, осмислення ними обмеженості стереотипності щодо виконання статевих ролей, адаптованість до емоційних і поведінкових проявів щодо осіб протилежної статі. Водночас дві третини хлопців і менше ніж половина дівчат володіють слабко розвиненими толерантними якостями, що може пов'язуватися 3 упередженим ставленням до представників різної статі, дотриманням стереотипності, домінуванням обмежених поглядів і небажанням виходити за межі самоусвідомлення, нестабільністю емоційних і поведінкових реакцій, впевненістю у марності налагодження міжстатевих стосунків у професійних і міжособистісних взаєминах.

Гендерну толерантність необхідно аналізувати з позиції структурності, адже прояв толерантності не є результатом лише особистісних якостей суб'єктів спілкування і взаємодії. В процесі дослідження гендерної толерантності, як комплексної якості особистості, доцільним було вивчення її компонентів - емоційного, когнітивного і поведінкового.

Зідно з кількісними показниками, високий рівень когнітивного компонента гендерної толерантності спостерігається у 20,70\% дівчат і 2,00\% хлопців. Такі особистості визнають неоднополярність суспільства, володіють достатнім арсеналом знань і досвіду для встановлення гармонійних стосунків, схильні до саморозвитку й саморефлексії, усвідомлюють власні гендерні якості, відступають у конфліктах, не підкорюються традиційним гендерним стереотипам та упередженням, здатні до безоцінного ставлення до представників різних статей.

Середній рівень когнітивного компонента свідчить про вибірковість та ситуативність у сприйнятті різних думок, якостей та ідентичності, визнанні права на відмінність, у слідуванні стереотипам. Він властивий $66,70 \%$ дівчат і 43,00\% хлопців, які здебільшого воліють слідувати власним судженням, сформованим на основі деяких стереотипів, в оцінці людей, які їх оточують, керуються лише особистою зацікавленістю та вже засвоєними знаннями, відчувають напругу при адаптації до соціальних змін та оточення.

Про несформованість когнітивного компонента (низький рівень) свідчить однополярність особистості у судженнях і сприйманнях, чітке розмежування статевих ролей i вимогливість до їх виконнання, пріоритетність однієї статі (найчастіше власної), жорсткість у вимогах щодо гендерної ідентичності, як до власної статі, так і до протилежної. Такі якості виявлено в 17,30\% дівчат і 54,20\% хлопців. Вони не схильні усвідомлювати і 
визнавати багатомірність світу, володіють зниженою рефлексивністю, обмеженістю знань і досвіду, а відхилення від визначеної ними норми сприймають досить вороже.

Дослідження емоційного компонента засвідчило, що в 9,3\% дівчат і 0,7\% хлопців його розвиток знаходиться на високому рівні. В цих юнаків і юнок помічена підвищена сприйнятливість до проявів насильства в гендерних стосунках, адже налаштовані на доброзичливу взаємодоповнюючу взаємодію. Вони визнають цінність кожної особистості, незалежно від ії статевої чи гендерної ідентичності. В них добре розвинена емоційна сфера, високий адаптивний потенціал, розвинена емпатійність, відсутні агресивні прояви у взаємодії з представниками власної та протилежної статі, $є$ схильність до встановлення партнерських стосунків із представниками різних статей.

Для особистостей $з$ середнім рівнем розвитку емоційного компонента властиві особистісна замкненість, знижена емоційність. Рефлексія емоційних станів у них має ситуативний характер, самоконтроль і саморегуляція виявляються лише у випадках особистої зацікавленості. Такий рівень емоційного компонента діагностовано у 65,70\% дівчат і 43,00\% хлопців. Визначальними характеристиками для них $є$ такі: нерозуміння певних емоцій, способів їх прояву, почуття зверхності над особами протилежної статі; обмеженість міжособистісного та міжстатевого спілкування.

Низький рівень емоційного компонента спостерігається у 24,00\% дівчат і 56,30\% хлопців. Для них характерні: відсутність саморегуляції, знижений самоконтроль, агресивність у емоційних проявах, відсутність диференціації емоційних проявів. У ситуації міжстатевої взаємодії вони виявляють емоційно-ворожі реакції у відповідь на неприйнятні для них емоційні прояви та реакції; чітко слідують стереотипам і вимагають цього від людей, які їх оточують; завищують значущість власної статі; нове та невизначене може зумовити в них стан фрустрації; схильні до конфліктної взаємодії.

Про сформованість поведінкового компонента гендерної толерантності свідчить високий рівень, який визначено в 14,00\% дівчат і 2,80\% хлопців. Вони виявляють толерантне ставлення до різних чоловічих і жіночих моделей поведінки, комунікативну компетентність i культуру при встановленні міжособистісних і міжстатевих контактів, адаптивність поведінки у конфліктній взаємодії. Також у них спостерігається здатність до самоаналізу поведінкових проявів і реакції, спрямованість на міжстатеву взаємодію, конструктивне вирішення суперечливих ситуацій, відтворення в своїй діяльності ідеї гендерної рівності в суспільстві.

Середній рівень поведінкового компонента помічено в 66,70\% юнок і 41,70\% юнаків. Для них характерним є усвідомлений вибір професійної, соціальної, громадської діяльності та поведінки, відповідно до особистої гендерної ідентичності; орієнтація на спілкування 3 особами протилежної статі, навіть із тими, які не відповідають своїй гендерній ідентичності. Водночас вони всіляко приховують неприязне ставлення до осіб протилежної статі чи невідповідної гендерної ідентичності при небажанні взаємодіяти або публічно негативно висловлюватися на їхню адресу, що нерідко є каталізатором конфліктних ситуацій.

Досліджуючи показники низького рівня поведінкового компонента гендерної толерантності, ми визначили його притаманність 55,50\% хлопців і 19,30\% дівчат. Це дало можливість констатувати в них поведінку суворо відповідну до статевої належності, вибір і здійснення професійної, соціальної та міжособистісної діяльності, відповідно до гендерних стереотипів. У міжособистісній взаємодії вони схильні виявляти агресію, зневажливе 
ставлення до осіб протилежної статі, використовувати вербальні образи, насильницькі методи взаємодії до представників обох статей.

\section{Висновки}

Узагальнені результати дослідження особливостей гендерної толерантності юнаків та юнок можна схарактеризувати такими рівнями: високий - володіють достатнім досвідом міжстатевої взаємодії та спрямовані на збагачення й розширення знань умінь і навичок щодо такої взаємодії; достатньо емпатійні; приймають індивідуальні особливості кожної особистості, незалежно від іiі статевої належності, налаштовані на партнерську взаємодію; володіють розвиненими комунікативними якостями; середній - володіють достатніми знаннями і навичками міжстатевої взаємодії, проте не завжди використовують їх у повсякденній життедіяльності; іноді, можуть виявляти байдужість до представників протилежної статі; іноді можуть слідувати деяким гендерним і статевим стереотипам у процесі партнерської взаємодії; комунікативні якості досить розвинені; низький - їм притаманний обмежений досвід та уміння міжстатевої взаємодії; погано орієнтуються в емоційних проявах і реакціях, як власних, так і людей, які їх оточують; мають певні труднощі у встановленні контактів з представниками обох статей, зокрема й комунікативні.

Емпіричне дослідження структурності гендерної толерантності проводилося шляхом аналізу показників сформованості таких компонентів гендерної толерантності, як: когнітивний - містить такі складники, як досвід і навички міжстатевої взаємодії; їх розвиток сприяє усвідомленню відмінностей між представниками різної статі, вдосконаленню особистісних якостей, які необхідні для подальшої оптимізації міжстатевих стосунків; емоційний - характеризується емоційною стійкістю, ціннісним ставленням до емоційних станів, як своїх, так і інших людей; сформованість цих складників сприятиме усвідомленню власних емоційних проявів, розвитку емпатійності, емоційної чуттєвості, прийняттю емоційних станів людей, які їх оточують, що $є$ орієнтирами успішної, продуктивної міжстатевої взаємодії й, відповідно, гендерній толерантності; поведінковий - містить гнучкість поведінкових проявів, спрямованість на компромісне вирішення конфліктних ситуацій, що впливає на вміння свідомо керувати власними діями при міжстатевій взаємодії. Достатній розвиток цих компонентів дозволить правильно рефлексувати життєві ситуації, прогнозувати емоційні стани та поведінкові акти партнера зі взаємодії.

Перспективи подальших досліджень вбачаємо в дослідженні психологічних чинників розвитку та прояву гендерної толерантності, розробці розвивальної програми, що сприятиме оптимізації розвитку якостей гендерно-толерантної особистості.

\section{Література}

1. Баева, Л.В. (2009). Толерантность: идея, образы, персоналии. (Монография). Астрахань. Режим доступу: http://forum.urgi.info/index.php

2. Кон, И.С. (1989). Психология ранней юности. Москва : Просвещение.

3. Малихін, О.В. (2017). Принципи організації самостійної освітньої діяльності студентів. Педагогіка формування творчої особистості у вищій $і$ загальноосвітній школах, 53, 482490. Режим доступу: http://nbuv.gov.ua/UJRN/Pfto_2017_53_63

4. Мацьковський, М.С. (1995). Семья на пороге третьего тысячелетия. Центр общечеловеческих изенностей. Москва.

Режим доступа: https://www.isras.ru/publ_mainlist.html?id=468 
5. Мириманова, М.С. (2002). Толерантность как проблема воспитания. Развитие личности. 2, 104-116.

6. Надолинская, Л.Н. (2008). Конструирование гендерного дискурса и стратегии гендерного партнерства (Теоретические представления и реалии современной России). (Автореф. дисс. д-ра. философ. наук). Ростов-на Дону.

7. Оконешникова, Н.Л. (2004). Проблема толерантности личности в современной зарубежной психологии. Методологические проблемы современной психологии: иллюзии и реальность: Материаль Сибирского психологического Форума. (2. Томск, 16-18 сентября 2004 г.). (215-221).

8. Солдатова, Г.У., \& Филилеева, Е.В. (2006). Толерантность, социальное доверие и ксенофобия: определяющие факторы и группы риска. Тетради Международного университета в Москве, 6, 154-176.

9. Ставицька, С.О. (2014). Соціально-психологічні особливості реалізації потреби в саморозвитку, самооцінки життєвих цілей та самоставлення як компонентів розвитку самосвідомості в юнацькому віці. Проблеми сучасної психології: зб. наук. праць Кам'янець-Подільського нащіонального університету імені Івана Огієнка, Інституту психології імені Г.С. Костюка НАПН України, 23, 595-607.

10. Рибалка, В.В. (2018). Методологічні засади теоретичної та практичної психології: особистість, психологічна діяльність, духовність. Психологія і особистість, 1, 9-19.

11. Эриксон, Э. (2000). Детство и общество. Сакт-Петербург.

12. Grünberg, L. (2011). From Gender Studies to Gender IN Studies and beyond : case studies on gender-inclusive curriculum in higher education. European Center for Higher Education, Bucharest, 7-13.

13. Kuzmenko, R.I. (2019). Gender Partnership and Tolerance Phenomenon. Антропологічні виміри філософських досліджень, 15, 73-81.

14. Stavytskyi, G. (2019). Psychological and social factors of the development of ethnic selfconsciousness of personality in youthful age. Problem space of modern society: philosophicalcommunicative and pedagogical interpretations: collective monograph. Part II.Warsaw.

\section{References}

1. Baeva, L.V. (2009). Tolerantnost: ydeia, obrazbl, personalyy. [Tolerance: idea, images, personalities] Astrakhan. Retrieved from http://forum.urgi.info/index.php [in Russian].

2. Kon, Y.S. (1989). Psykholohyia rannei yunosty [Psychology of early adolescence]. Moscow : Prosveshchenye [in Russian].

3. Malykhin, O.V. (2017). Pryntsypy orhanizatsii samostiinoi osvitnoi diialnosti studentiv. [Principles of organization of independent educational activity of students.]. Pedahohika formuvannia tvorchoi osobystosti u vyshchii i zahalnoosvitnii shkolakh - Pedagogy of formation of creative personality in higher and secondary schools, 53, 482-490. Retrieved from http://nbuv.gov.ua/UJRN/Pfto_2017_53_63 [in Ukrainian].

4. Matskovskyi, M.S. (1995). Semia na porohe treteho tblsiacheletyia. Tsentr obshchechelovecheskykh tsennostei [Family on the threshold of the third millennium. Center for universal values]. Moscow. Retrieved from https://www.isras.ru/publ_mainlist.html?id=468 [in Russian].

5. Myrymanova, M.S. (2002). Tolerantnost kak problema vospytanyia [Tolerance as a problem of education]. Razvytye lychnosty - Personality development, 2, 10-116. 
6. Nadolynskaia, L.N. (2008). Konstruyrovanye hendernoho dyskursa y stratehyy hendernoho partnerstva (Teoretycheskye predstavlenyia y realyy sovremennoi Rossyy). [Constructing gender discourse and gender partnership strategies. (Theoretical ideas and realities of modern Russia)]. Extended abstract of Doctor's thesis. Rostov-na Donu [in Russian].

7. Okoneshnykova, N.L. (2004). Problema tolerantnosty lychnosty v sovremennoi zarubezhnoi psykholohyy [The problem of personality tolerance in modern foreign psychology]. Metodolohycheskye problembl sovremennoi psykholohyy : Materyalbu Sybyrskoho psykholohycheskoho Foruma - Methodological problems of modern psychology: illusions and reality: Proceedings of the Siberian Psychological Forum. (Tomsk, September 16-18, 2004). (p.p..215-221). Tomsk [in Russian].

8. Soldatova, H.U., \& Fylyleeva, E.V. (2006). Tolerantnost, sotsyalnoe doverye y ksenofobyia: opredeliaiushchye faktorы y hruppы ryska. [Tolerance, social trust and xenophobia: determinants and risk groups]. Tetrady Mezhdunarodnoho unyversyteta v Moskve - Notebooks of the International University in Moscow, 6, 154-176. Moscow [in Russian].

9. Stavytska, S.O. (2014). Sotsialno-psykholohichni osoblyvosti realizatsii potreby v samorozvytku, samootsinky zhyttievykh tsilei ta samostavlennia yak komponentiv rozvytku samosvidomosti v yunatskomu vitsi [Socio-psychological features of the realization of the need for self-development, self-assessment of life goals and self-esteem as components of the development of self-awareness in adolescence] Problemy suchasnoi psykholohii: Zbirnyk naukovykh prats Kamianets-Podilskoho natsionalnoho universytetu imeni Ivana Ohiienka, Instytutu psykholohii imeni H.S. Kostiuka NAPN Ukrainy - Problems of modern psychology: Collection of scientific works of Kamyanets-Podilsky National University named after Ivan Ogienko, Institute of Psychology named after GS Kostyuk NAPS of Ukraine, 23, 595-607 [in Ukrainian].

10. Rybalka, V.V. (2018) Metodolohichni zasady teoretychnoi ta praktychnoi psykholohii: osobystist, psykholohichna diialnist, dukhovnist [Methodological principles of theoretical and practical psychology: personality, psychological activity, spirituality]. Psykholohiia $i$ osobystist - Psychology and personality, 1, 9-19 [in Ukrainian].

11. Erykson, Э. (2000). Detstvo y obshchestvo [Childhood and society]. Sankt-Peterburg [in Russian].

12. Grünberg, L. (2011). From Gender Studies to Gender IN Studies and beyond : case studies on gender-inclusive curriculum in higher education. European Center for Higher Education, Bucharest, 7-13.

13. Kuzmenko, R.I. (2019). Gender Partnership and Tolerance Phenomenon. Antropolohichni vymiry filosofskykh doslidzhen - Anthropological dimensions of philosophical research, 15, 7381.

14. Stavytskyi, G. (2019). Psychological and social factors of the development of ethnic selfconsciousness of personality in youthful age. Problem space of modern society : philosophicalcommunicative and pedagogical interpretations: collective monograph. Part II.Warsaw. 


\title{
PSYCHOLOGICAL FEATURES OF MANIFESTATION OF GENDER \\ TOLERANCE IN ADOLESCENCE \\ Olena Prachenko \\ Senior Lecturer of the Department of Psychosomatics and Psychological Rehabilitation \\ National Pedagogical Dragomanov University \\ 9, Pyrohov Str., Kyiv, Ukraine, 01601 \\ o.k.prachenko@npu.edu.ua, https://orcid.org/0000-0001-5174-2547
}

\begin{abstract}
The article exposes the definition of psychological features of gender tolerance and its structural components in adolescence. This age period is marked by the emergence of a new social situation of development, the center of which is the transition to independent living (the beginning of professional development, implementation of life plans). Intensive development of self-awareness continues, young people self-determine in the system of moral values, principles, norms and rules of conduct, are aware of personal social responsibility. According to this situation of development of the young generation in the conditions of transformational processes in economic, political and social spheres, the issue of harmonization of intersex relations of youth through education of tolerant attitude to representatives of one`s own and opposite sex is important. Manifestation of gender tolerance in adolescence contributes to: the creation of psychologically comfortable conditions for joint activities of both sexes; achieving interpersonal and intergroup mutual understanding and respect in various spheres of life interaction; providing effective psychological and pedagogical conditions for the development of young men and women of the necessary individual and personal qualities for successful resistance to stereotypes and pressure of society. The purpose of the article is to study the psychological features of the manifestation of gender tolerance and the formation of its components among young men and women. The objectives of the study are: selection and implementation of methods to determining the degree of manifestation of gender tolerance by adolescents; study of its structure and levels of formation of cognitive, emotional and behavioral components. In the process of the empirical research we have used: the method of "VIKTI: types and components of tolerance" (author G.L. Bardier), quantitative and qualitative analysis of the results performed on the scales "gender tolerance", "cognitive component", "affective component", "Activity-style component" of gender tolerance. Based on certain levels of gender tolerance, it was found that more than half of adolescents have a level of gender tolerance at a medium (close to low) level; about a third of young people have a low level of gender tolerance; and only the fifth part has formed (high level) gender tolerance. When analyzing the formation of such components of gender tolerance (cognitive, emotional, behavioral), it was found that their reduced performance is more perculiar for boys that is manifested in their reduced reflexivity, limited emotional and behavioral self-regulation.
\end{abstract}

Keywords: tolerance, gender tolerance / intolerance, cognitive component of gender tolerance, emotional component of gender tolerance, behavioral component of gender tolerance.

Подано 10.12.2020

Рекомендовано до друку 22.12.2020 